\title{
Institutions, Institutional Reform and Economic Development: The Visible Hand of Corruption in Nigeria ${ }^{4}$
}

\author{
John F. E. Ohiorhenuan'"
}

\section{Introduction}

This article aims for a better understanding of the links between institutions and inefficient development outcomes in Nigeria, and the nature of, and reasons for the persistence of the country's institutional crises. It is argued that, in the context of Nigeria's development, corruption provides a large part of the answers and specifically, that corruption has become the main driver of institutional evolution. As such, dealing with corruption has to be at the core of institutional reform, the article advances some ideas for realizing better outcomes in the country's institutional evolution.

There are two reasons for this paper's focus on corruption. First, a great deal of reform of economic institutions has already taken place in Nigeria, particularly during the last 15 years. Among other things, the government does seem to have a reasonably good hold on the macroeconomic management fundamentals, and one is comfortable in the assumption that there are no major structural deficiencies in our core economic oversight entities, like Finance, Planning, or the Central Bank. Furthermore, the country already has in place a slew of essential institutions designed to restrain undesirable economic behaviour, such as the Budget Monitoring and Price Intelligence Unit (BMPIU), the Independent Corrupt Practices Commission (ICPC), and the Economic and Financial Crimes Commission (EFCC). Finally, the recent radical restructuring in the financial sector is further indication that understanding of the economic fundamentals is not our problem.

To be clear, this is not to suggest that the performance of Nigeria's macroeconomic institutions is in anyway outstanding. The absence of structural deficiencies does not necessarily mean an absence of behavioural deficiencies. Because corruption is a matter

\footnotetext{
${ }^{4}$ This paper is a slightly revised version of the author's keynote address delivered at the $54^{\text {th }}$ Annual Conference of the Nigerian Economic Society, held in Abuja from September 17 - 19, 2013. ${ }^{5}$ The author gratefully acknowledges the suggestions of participants at the conference and in particular, the written comments of Sam Olofin. Nonetheless, any remaining errors are mine alone.
} 
of institutional quality, it is essential to examine closely the actual functioning of our institutions and institutional reform process.

Second, there is interesting research and policy level work to be done at the intersection of corruption, institutions and institutional reform. Of Nigeria's many institutional challenges, corruption is such a major presence in the lives of the citizens, with high and widely acknowledged impact. Several researchers have been paying attention lately to the subject. While some good research has been done, it has hardly received the rigorous intellectual attention it deserves. Hopefully, this paper will contribute to stimulating additional work in that direction.

To begin by clarifying the meaning of institutions, Douglass North (1981:201-202) defines an economic institution as " a set of rules, compliance procedures and moral and ethical behavioral norms designed to constrain the behavior of individuals in the interests of maximizing the wealth or utility of principals. "Institutions consist of both informal constraints such as taboos, customs and traditions, and formal rules like constitutions and laws. ${ }^{6}$

The notion of agency implied in North's definition has been queried. Pande and Udry (2005) argue, for instance, that institutions may not necessarily be the product of a design consciousness and that, even if they were, their actual operation may be different from original intent. As such, they suggest, the focus should be on de facto more than dejure institutions.

When economic agents act consistently over time according to their subjective preferences and expectations, the observed reality tends to confirm the initial preferences and beliefs, which are then reproduced as a guide for further actions (Aoki 2001: 3). For example, suppose the government prohibits the importation of some goods but people continue to import them by bribing customs officers. If this practice becomes prevalent and is so widely accepted that it is more effective to circumvent the law through bribery, than to follow it, it is logical to regard this practice as the institution, rather than the ineffective law. In game-theory language, institutions are self-sustaining salient patterns of social interactions as represented by universally understood rules, and incorporated as shared beliefs about how the game is to be played (Aoki 2007: 7).

This slightly broader conception of institutions enables us to explore more fully the idea of corruption as the primary driver of contemporary institutional evolution in the Nigerian context, without falling into the Panglossian trap of accepting the actually existing system as the best of all possible worlds.

The institutions in the research and analysis focus of the New Institutionalists are those that foster the development of the market (North 1990). These include the legal system, the property rights regime, a minimally interventionist economic policy and regulatory regime flexible labour markets and accommodating financial institutions. 
The article unfolds as follows. The next section provides a quick overview of the literature on how institutions matter for development. Section III explores the nature of institutional failure in Nigeria, highlighting the major role that corruption has come to play in it. The following section suggests some elements towards a strategy for managing corruption in Nigeria. The conclusion then follows with a summary and some final reflections.

\section{How Institutions Matter for Development}

For now we see through a glass, darkly... (1 Corinthians 13: 12, King James Version) In spite of much analytical work during the last 30 years, there is still no unambiguous understanding of how institutions change and how they influence growth and development. The New Institutional Economics ${ }^{7}$ postulates that institutions are the primary cause of economic development, and are the key to understanding why some societies are capable of sustained economic and political development and others are not (North 1981, 1990, 1997; Acemoglu, Johnson, and Robinson 2002; Acemoglu and Robinson 2012; Greif 2006; Rodrik, Subramanian, and Trebbi 2004). In the words of Douglass North (1997: 224): "the primary source of economic growth is the institutional/ organizational structure of a political economy...". He also says that the: "Third World countries are poor because their institutional constraints define a set of payoffs to political economic activity that do not encourage productive activity." (North 1990: 110).

In "Why Nations Fail", Acemoglu and Robinson (2012) emphasise that what matters most in the success or failure of nations are not their economic policies, geography, culture, or value systems, but their institutions. In their view, countries' political institutions determine their economic institutions, which in turn determine their ultimate success or failure. They divide political institutions into two kinds - "extractive" institutions in which a small group of individuals exploit the rest of the population, and "inclusive" institutions in which many people are included in the governance process. They argue that inclusive regimes provide basic public services such as justice, the enforcement of contracts, and education. Consequently, they enable innovation to thrive and generate sustained growth. Extractive institutions, on the other hand will ultimately fail because they do not elicit the innovations and "creative destruction" that are needed to push the growth frontier.

Specifically for African countries, Acemoglu and Robinson argue that they are caught in economic and political institutions that are not conducive to economic progress.

${ }^{7}$ The New institutional economics, which has grown in influence over the last five decades, focuses on how laws, social norms, and legal obligations undergird economic activity. It extends neoclassical theory by abandoning instrumental rationality while retaining its fundamental assumption of scarcity as the basis of the choice theory. 
They contend that their transition from colonialism did not generate a shift from an extractive to an inclusive regime. Rather, the post-colonial state simply represented a change of extractive institutions into African attire (Acemoglu and Robinson 2010).

A rich literature has developed on the relationship between institutions and development. From this body of work, explanations for underdevelopment may be grouped according to those that stress: "colonial heritage", "political conflict", or "beliefs and norms" (Shirley 2008).

The Colonial Heritage class of explanations suggests that colonial powers created institutions that mirrored their own domestic institutions. Other analysts emphasise the legal system, contending that countries that inherited English common law systems developed institutions that were capable of limiting the state's power, enforcing contracts, and protecting property rights. On the other hand, countries with civil law systems inherited from the French developed a state more prone to undermining individual property rights.

A variation of this argues that the kinds of institutions Europeans imposed in their colonies depended on the conditions they found there. In richer areas that had a large population that could be enslaved or a climate that supported plantation agriculture or mining, they created or adapted oppressive production, tax and tribute systems that concentrated political power in a few hands. Such concentration allowed the few to extract resources from the rest of the population. On the other hand, in places where the population was relatively sparse or the land less suited for plantations, Europeans settled in larger numbers bringing beneficial institutions that supported private property and wider participation.

\section{Political Conflict}

Some scholars promote the notion that the weakness of institutions is the result of too little political conflict. In societies where elites did not need to make compromises, raise revenues, or win supporters to defeat foreign enemies, there was no need for strong institutions (Bates 2001). A variant is the suggestion that where land was ample, as ir Africa, the pre-colonial African states did not need to fight to defend their boundaries As such, they did not have to build effective bureaucracies to raise funds or maki political concessions to their citizens to persuade them to support the war effort (Herbs 2000). ${ }^{8}$

\footnotetext{
${ }^{8}$ Herbst argues that external threats in South Korea and Taiwan enabled their states to extract more resources from their citizens and develop more efficient mechanism to collect resources and contain dissident groups. It is not clear, however, why the same dynamic has not worked to the same effect contemporary North Korea. These explanations also do not seem able to explain the rise and fall of the major African kingdoms and empires that emerged from conquest and annexations, like the Song Empire in the $16^{\text {th }}$ century. More recently in historical terms, the Sokoto Caliphate at its height include over 30 different emirates, with each Emirate leader appointed by the Sultan, although given we autonomy. It stretched 1,500 kilometers from Dori in modern Burkina Faso to southern Adamawa
} 
Another strand of the literature argues that countries' beliefs and norms explain why some countries developed better institutions than others. Some countries had cultures that were inhospitable to markets or engendered mistrust, preventing them from building institutions that encourage trade and investment (Landes 1998, Putnam 1993).

Many questions can be raised regarding the acceptability of each of these explanations (Shirley 2008). For instance, on the colonial heritage explanation, why have countries with the same colonizer ended up with totally different institutional outcomes and why have the institutional matrices of different imperialists converged closer than those of their colonies? On the political conflict explanation, the reasons why elites were competitive in one locale and collaborative in another are too case specific for generalization. Counterfactually, non-involvement in border wars does not seem to have harmed Switzerland's institutional evolution.

Of particular relevance to Africa, it has been pointed out that Acemoglu and Robinson do not have an axiomatic definition of "inclusive" and "extractive" that is independent from actual outcomes (Boldrin, Levine and Modica 2012). As a result, the classification of historical institutions into either group ends up being based on revealed outcomes, thereby making the argument circular and subject to a selection bias. As a consequence, while many examples fit their theory reasonably well, many others are more difficult to align. It is empirically difficult to quantify what a "small" group means in the extractive institutions domain, or what "many" means in the inclusive institutions domain. ${ }^{9}$

Cross-country regressions on growth have been the preferred quantitative method for analysing the relationship between institutions and growth. Four sets of political and institutional variables have typically been used in these cross-country regressions (Alesina 1997).

(i) Variables that capture the quality of government and institutions such as measures of corruption;

(ii) Those that capture protection of property rights and enforcement of contacts;

(iii)Those that capture institutional variables, such as whether or not the country is a democracy; and

Cameroon and included Nupe lands, Ilorin in Yoruba land and much of the Benue River valley (Metz, 1991). Without getting drawn into counterfacrual angst, it's not obvious that the caliphate or the similar, if smaller kingdoms in Southern Nigeria would not have evolved the necessary "progressive" institutions had British imperialism not interrupted the evolutionary process.

\footnotetext{
${ }^{9}$ In what sense, Boldin and his co-authors ask, were the institutional arrangements of the Roman Empire "inclusive" relative, for example, to those of the Communist USSR? Or in what sense did the Spanish Kingdom turn from "inclusive" to "extractive" between the XV and the XVII century?
} 
(iv)Those that capture the socio-economic characteristics of the country such as income inequality or ethnic composition.

Alesina points out that there is a high potential of relatedness among these variables, which does not necessarily indicate causation. It may simply be that political stability, bureaucratic efficiency, and low levels of corruption are positively associated and mutually reinforcing. Good institutions facilitate growth, and as income levels rise it is easier to maintain political stability and efficient institutions.

Other major issues have been raised concerning these cross-country studies in general (Shirley 2008, Chang 2011). For instance, it is not always clear that all the explanatory variables can accurately be called institutions. Secure property rights, for instance, are not institutions but outcomes. Ethnic fragmentation is a socio-economic condition. There is no reason to assume that these variables are not direct determinants of growth, rather than proxies for institutions. Moreover, the typical institutional variable is an aggregate. Institutional quality measures aggregate subjective ratings of outcomes of a host of different specific institutions. A variable such as civil liberties, for instance, includes rules governing inter alia, franchise, association, speech, information, privacy, property, and crime; as well as norms of trust and civic mindedness. Even an ostensibly straightforward notion like 'property rights system', consists of so wide a range of component institutions ${ }^{10}$ that adding them up doesn't seem meaningful.

To synthesise the various queries: despite the painstaking research and progress to date, the evidence on why and how institutions change is not solid. The tendency for institutional variables to dominate in studies explaining growth is not backed by a theory to help transform regularity into explanations. Moreover, the co-relatedness may indicate that causality runs stronger from development to institutions, rather than the other way around. In Chang's words: "good development results eventually create good institutions". This directionality may be a better fit for the development stories of countries like South Korea and Taiwan. Engerman and Sokoloff (2008: 641) caution against institutional fetishism:

\begin{abstract}
Although we cannot conceive of processes of economic growth that do not involve institutional change, ... one should be cautious about grounding a theory of growth on institutions...[Different institutional structures have often been found to be reasonable substitutes for each other, both in dissimilar as well as similar contexts. The historical record, therefore, does not seem to support the notion that any particular institution, narrowly defined, is indispensable for growth. ... [T] he evidence that there are systematic patterns to the ways institutions evolve undercuts the idea that exogenous change in institutions is what powers growth. Institutions matter, but our thinking of how they matter should recognize that they are profoundly influenced by the political and economic environment, and that if any aspect of institutions is crucial for growth, it is-that institutions change over time as circumstances change.
\end{abstract}

\footnotetext{
${ }^{10}$ Property rights system includes for instance, land law, urban planning law, zoning law, tax law, inheritance law, contract law, company law, bankruptcy law, intellectual property laws, customs regarding common property and much else.
} 


\title{
Corruption and Institutional Failure in Nigeria
}

\author{
"You tief one kobo dey put you for prison; \\ You tief 10 million na patriotism. Dem go give you chieftaincy and national honour." \\ You tief even bigger, datnarumour (Wole Soyinka, Unlimited Liability Company, \\ Ewuro Productions, 1983). \\ "Corruption is our only hope. As long as there's corruption, there'll be merciful judges \\ and even the innocent may get off." (Bertolt Brecht, Mother Courage and Her \\ Children", Grove Press, New York, 1966: 61).
}

Over the past 40 years corruption has become the prism through which Nigeria is seen the world over. All our institutions are perceived as affected and those institutions, like the judiciary and the legislature, that are meant primarily to control abuses of power by public officials, are considered heavily tainted. See Box 1 for an excerpt from $a$ report on Nigeria presented earlier this year to the United States Congress, which exemplifies the global image of Nigeria. This section highlights the distinguishing characteristics of corruption in Nigeria and how corruption has undermined institutional evolution.

\section{Box 1: Corruption in Nigeria: excerpts from a U.S. report}

Officials frequently engage in corrupt practices with impunity and massive, widespread, and pervasive corruption affects all levels of government and the security forces. There was a widespread perception judges were easily bribed and litigants could not rely on the courts to render impartial judgments. Citizens encountered long delays and alleged requests from judicial officials for bribes to expedite cases or obtain favorable rulings. Police corruption remains rampant...In 2010 Human Rights Watch released "Everyone's in on the Game", a report on corruption and human rights abuses by the police. Information compiled from 145 interviews documented pervasive police extortion committed with impunity by police officers throughout the country. Police demanded bribes, threatened arrest and physical harm, and enforced a system of "returns" in which officers must pay up the chain of command a share of the money they extorted from the public...On April 18, a House of Representatives Committee, charged with investigating the fuel subsidy program from 2009 to 2011 , released a report showing massive fraud, corruption, and inefficiencies in the operation of the program. The report alleged misappropriation of nearly half the subsidy funds, with poor or zero oversight by government agencies. It estimated 1.067 trillion Naira ( $\$ 6.8$ billion) government money got lost to "endemic corruption and entrenched inefficiency"...In July the government released a list of those who had benefited illegally from the subsidy program, which included relatives and colleagues of key government officials... In May 2011, the EFCC arrested a former minister of works and housing on 24 counts of fraudulently awarding contracts, money laundering, and embezzlement of 75 billion Naira (\$480 million)... In June 2011, the EFCC arrested a former Speaker and Deputy Speaker of the House of Representatives, for the alleged misappropriation of one billion Naira ( $\$ 6.4$ million) and 40 billion Naira (\$256 million) respectively... In October 2011, the EFCC arrested four former governors who vacated office earlier in the year. The four allegedly misappropriated or stole 58 billion Naira (\$372 million), 25 billion Naira ( $\$ 160$ million), 18 billion Naira ( $\$ 115$ million), and 12.8 billion Naira ( $\$ 82$ million), respectively...On February 27 2012, a former Delta State governor pleaded guilty to charges in the Southwark Crown Court in 
London to charges of money laundering and other financial crimes totaling 12.4 billion naira ( $\$ 79$ million) he had committed during his eight years in office. On April 17, the $\mathrm{c}^{\wedge}$ purt sentenced him to 13 years in prison...

Source: US Department of State, 2013 Country Reports on Human Rights Practices for 2012: Nigeria. http:// $\underline{\text { lvww.state.uov/i/drl/rls/hiTpt/humanrightsreport/index.htni'?year=2012\&dlid=20413 }}$

\section{Types of corruption in Nigeria}

In the development literature, corruption is typically defined roughly as the abuse of public office or entrusted power for private gain (World Bank 1997, Transparency International 2009: 14). Public office is abused for private gain when an official accepts, solicits, or extorts a bribe, or when private agents actively offer bribes to circumvent public policies and processes for competitive advantage and profit. Public office can also be abused for personal benefit, even if no bribery occurs, through patronage and nepotism, the theft of state assets, or the diversion of state revenues (World Bank 1997). Corruption includes bribery, extortion, influence peddling, nepotism, fraud, the use of "speed money" and embezzlement. ${ }^{11}$

It should be noted that corruption is not limited to the official domain and there is no suggestion in this article that official corruption is the only important aspect. The private sector is as prone as the public sector to abuse of power of position for private gain. It is also almost always implicated in government corruption as a motivator of corrupt behavior and a repository for its proceeds. The focus therefore here on official corruption is due merely to the need to keep the scope of discussion manageable. Several approaches to classifying corruption have been proposed (Kpundeh 1997, Karklins 2005, Vargas-Hernandez 2009). The easiest approach analytically may be to distinguish between petty, grand and political corruption, depending on the amounts of money lost and the sector where it occurs.

Petty corruption consists of small-scale embezzlement and misappropriation; bribery demanded by or offered to low level officials in order to bend rules; use of licensing and inspection powers for extortion, and perpetrating minor acts of favouritism. The typical incident of petty corruption involves a private citizen dealing with a low-level government bureaucrat in a straightforward transaction such as goods clearance or issuance of driver's licence or passport. These acts of corruption can be subtle - a mere gesture or hint that a small consideration is expected. It can also be more direct, an explicit demand or a threat that the file could stop "moving" if a gift was not offered. ${ }^{12}$

\footnotetext{
"Nigerians will be familiar with some of the euphemisms for corruption: kickback, egimje, kola,ten percent, family support, settlement, etc.

${ }^{12}$ In Nigeria, even the lowliest of officials may expect a small consideration to speed up a file's or dossier's travel from one desk to another. The popular satirist Moses Olaiya (Alawada) had a television sketch about 30 years ago in which a messenger explained to a supplicant how files needed to be "carried" (for a small fee) because files are cripples!
}

104 Annals of the Social Science Academy of Nigeria, No 20, 2015 
Grand corruption is misuse of public office at higher levels within the state (Rose-Ackerman 1999:27). It includes large-scale embezzlement and misappropriation via public procurement; payment for non-existent goods or services; contrived losses in public sector entities; large kickbacks in government purchases and contracts; employment of "ghost workers" on the government payroll and extending economic privileges to special interests. The extreme example of grand corruption is "state capture", which is when top politicians and bureaucrats collude with private actors to turn the state into a private moneymaking machine.

Political corruption includes gross abuse of the country's mechanisms of restraint: legislative and judicial processes, as well as auditing, investigatory, and oversight powers; , subversion of electoral processes through vote-buying and bribery of accountable officials; large-scale assignment of public property to privileged interests; politically motivated loans by banks and financial institutions; large contributions from public coffers to private causes and large political donations and bribes to parties and party officials. ${ }^{13}$ Without aiming to be comprehensive, Table I. ${ }^{14}$, highlights some major expressions of these types of corruption in Nigeria.

The former head of the Economic and Financial Crimes Commission (EFCC) asserted publicly that between 1960 and 1999, Nigerian officials had "stolen or wasted" ${ }^{15}$ more than $\$ 440$ billion, a sum that is six times the Marshall Plan (Ribadu 2009). He cited as examples the recent cases of how two State governors had blatantly appropriated public funds. One operated 25 bank accounts in London, and used front agents to acquire choice properties in major Western cities. The governor had accumulated $£ 10$ million in various accounts in London, while in Nigeria the EFCC was able to restrain proceeds of corrupt activities worth $\$ 34$ million. Another governor had four properties in London valued at about $£ 10$ million, and another in Cape Town valued at $\$ 1.2$ million. One million pounds in cash was found at his London apartment. The sum of $£ 2$ million was restrained at the Royal Bank of Scotland in London and over \$240 million in Nigeria. This was in addition to bank accounts traced to Cyprus, Denmark, USA and the Bahamas (Ibid.).

\footnotetext{
${ }^{13}$ The line between political and grand corruption should not be too finely drawn, as most cases of political corruption also involve bureaucrats and administrators in addition to politicians.

${ }^{14}$ It bears noting that different varieties of corruption are not equally harmful. Corruption that subverts the justice system or devastates social and economic development causes major damage. In comparison, paying speed money to get quicker access to public services and engaging in mild irregularities in campaign financing may be less damaging (Klitgaard 1998). While some may find this distinction between minor and major "sins" objectionable, I suggest that absolutism in the moral domain cannot always translate absolutely into the policy domain. To be sure, it is good and proper to stress that unrighteousness in any form is deplorable, but moral exhortation is not always effective economic policy.

${ }^{15}$ The difficulty of drawing the line accurately between corruption (implied in "stolen" and incompetence ("wasted") suggests that this might be an important area of research.
} 
Table 1. A Typology Of Corruption

\begin{tabular}{|c|c|c|}
\hline Type & Main Actors & Mode \\
\hline $\begin{array}{l}\text { Petty } \\
\text { corruption }\end{array}$ & $\begin{array}{l}\text { Low- and niid-level } \\
\text { public officials }\end{array}$ & $\begin{array}{l}\text { Small-scale embezzlement and misappropriation; bribery } \\
\text { to bend rules or ignore misdemeanours; using licensing } \\
\text { and inspection powers for extortion; minor favouritism }\end{array}$ \\
\hline $\begin{array}{l}\text { Grand } \\
\text { corruption }\end{array}$ & $\begin{array}{l}\text { High level public } \\
\text { officials; politicians; } \\
\text { representatives of } \\
\text { donor and recipient } \\
\text { countries; bureaucratic } \\
\text { elites; businessmen } \\
\text { and middlemen }\end{array}$ & $\begin{array}{l}\text { Large-scale embezzlement and misappropriation via } \\
\text { public procurement; payment for non-existent goods } \\
\text { or services; kickbacks; "ghost workers" on government } \\
\text { payroll; economic privileges given to special interests, }\end{array}$ \\
\hline $\begin{array}{l}\text { Political } \\
\text { corruption }\end{array}$ & $\begin{array}{l}\text { Top-level executive, } \\
\text { legislative and judicial } \\
\text { officials; bureaucratic } \\
\text { elites; politicians; big } \\
\text { business }\end{array}$ & $\begin{array}{l}\text { Abuse of legislative powers; corruption of the judicial } \\
\text { process; abuse of auditing, investigatory, and oversight } \\
\text { powers; Undermining electoral processes through vote- } \\
\text { buying and bribery of accountable officials, large-scale } \\
\text { assignment of public property to privileged interests; } \\
\text { large contributions from public coffers to private } \\
\text { causes; large political donations and bribes. }\end{array}$ \\
\hline
\end{tabular}

From the lowliest level of government functioning to the highest levels of state-society interaction, corruption has become so engrained in everyday social and economic transactions that it has become the primary institution determining the rules of the game for development in Nigeria. The depth of corruption in Nigeria may be appreciated by the fact that the country consistently ranks among the worst performers globally in the control of corruption. The 2012 report on the Corruption Perception Index (CPI) published by Transparency International (TI) ranks Nigeria number 139 out of 176 countries measured, with a score of 27 out of a maximum of 100. In the 2011 survey, Nigeria ranked $143^{\text {rd }}$ out of 182 countries (Transparency International 2013a). In 2008 Nigeria had ranked 121 st out of 183 countries on its Corruption Perceptions Index, reflecting perhaps, the government's efforts during the preceding eight years to improve accountability in the country.

Another survey by TI shows a perception of widespread corruption among the country's major institutions of policy, restraint and service delivery (Transparency International 
2013b) Respondents were asked the question: "Over the past two years how has the level of corruption in this country changed"? Seventy-two per cent said it has "increased a lot", 13 per cent said u"increased a little. A mere 7 per cent said it has stayed the same, while 8 per cent thought it had decreased a little. ${ }^{16}$ To the question: "over the past two years how has the level of corruption in this country changed", 72 per cent of respondents answered "a lot" and another 13 per cent said "a little". Ninety-four per cent of respondents perceived political parties as "corrupt or very corrupt", while 92 per cent perceived the police in the same light. Perhaps most disturbing, two-thirds of respondents felt the judiciary was "corrupt or very corrupt" (Table 2). In addition, 81 per cent of respondents answered that someone in their household had paid a bribe to the police services in the preceding 12 months. About one-quarter of respondents reported the same about the judiciary, the education sector, utilities and tax revenue services (Table 3 ).

Table 2: Percentage of Respondents Who Felt the Following Institutions in Nigeria Were Corrupt or Extremely Corrupt

$\begin{array}{lc}\text { Institution } & \text { Percentage } \\ \text { Political parties } & 94 \\ \text { Police } & 92 \\ \text { Legislature } & 73 \\ \text { Public officials \& civil servant } & 69 \\ \text { Judiciary } & 65 \\ \text { Education systems } & 54 \\ \text { Military } & 45 \\ \text { Medical and Health services } & 41 \\ \text { Business } & 41 \\ \text { Media } & 33 \\ \text { NGOs } & 32 \\ \text { Religious organisations } & 24\end{array}$

Source: Transparency International Global Corruption Barometer 2013. Available at: http:// vl'ww.transparency.org/scb2013/coiintty/? couiiti-v=nigeria

Table 3: Responses to Question: Have You or Anyone in Your Household Paid a Bribe to One of these Eight Services in the Last 12 Months? ${ }^{17}$

Service

Police

Registry/permit services

Utility

Tax revenue
Percentage of respondents reporting they paid bribe 81

22

\footnotetext{
${ }^{16}$ There is hope, however, in the fact that 56 per cent of respondents think ordinary people can make a 'Results shown for those who came into contact with a service difference in combating corruption own for those who cams
} 
Land services $\quad 17$

Education services $\quad 30$

Judiciary 24

Medical and health 9

Source: Source: Transparency International, Global Corruption Barometer 20IB/Nigeria http:/ Avww.trausparencv.ors/scb20] 3/countr|'/? counln'=Nigeria

Ten years ago, a study of governance and corruption led by the Institute for Development Research at Ahmadu Bello University, had also identified essentially the same public sector institutions among those that are perceived as most corrupt in the country (Table 4).

Table 4: Public Institutions Perceived as Corrupt (Ranked in a Descending Order of Corruption)

$\begin{array}{lc}\text { Institution } & \text { Rating } \\ \text { The Nigeria Police } & 1 \\ \text { Political Parties } & 2 \\ \text { National and State Assemblies } & 3 \\ \text { Local and Municipal Councils } & 4 \\ \text { Federal and State Executive } & 5 \\ \text { Councils } & 6 \\ \text { Traffic Police and Federal } & \\ \text { Road Safety Commission } & 7 \\ \text { Power Holding Company of } & \\ \text { Nigeria } & \end{array}$

Source:

FRN 2003. Nigeria Governance and Corruption Survey Study, page 18. As reported in: Musa 2011

\section{Characteristics of Corruption in Nigeria}

Three features of corruption in Nigeria are hereby highlighted. The first is that official corruption is the name of the game. Corrupt behavior is systemic in the country and has become a 'normal' feature of even the most routine interaction between citizen and state. The routinisation of corruption points to a classic collective action problem. Viewed from one agent's perspective, widespread corruption makes it too costly for any one agent to fight it. Indeed, it may generate positive incentives to join the bandwagon. This is so even when most people recognize that all would be better off if corruption were to be eliminated. The larger the number of corrupt agents, the greater the probability of a positive pay-off to a single actor from acting corruptly. This appears to have led to a selffulfilling high equilibrium level of corruption.

The second feature is that corruption pays. A large number of public officials derive a significant proportion of their incomes from corrupt sources on a permanent basis. The fact that corruption is a permanent income source for a large number of public official and civil servants creates an extremely large army of foot soldiers for corruption. The institutionalization of corruption means that agents begin to factor it into their decision making processes. It is not unheard of, for instance, for some police or customs official to base their lifetime savings and investment projections on the expectation of regular

108 Annals of the Social Science Academy of Nigeria, No 20, 2015 
incomes significantly higher than their official salaries and emoluments. The need for income predictability pushes them to develop appropriate income supplementation techniques.

These could range from mere receptiveness to offers of bribe to its aggressive solicitation. ${ }^{18}$ In this way, corrupt practices often become the sole channel for obtaining (not merely accelerating) a decision. More disturbingly, however, the line is sometimes blurred between accepting a bribe to accelerate a decision, to demanding a (higher) fee to alter a decision (as in changing a verdict from guilty to not guilty) or to pervert the integrity of an outcome (as in granting a certificate to an engineer who did not even attend engineering school. ${ }^{19}$

The third feature is that corruption rules. There is the strong tendency in Nigeria for the private gains of decision makers to be the major driver of government policy. Indeed, at the structural level, corruption has become the main engine of capital accumulation in the country. At one level, corruption may inflict severe developmental pathologies on social and economic processes. For example, government officials may favour certain kinds of expenditures that promote their interests than others, and economic agents may find it more profitable to engage in facilitation rather than direct production. For instance, corruption may distort the composition of government expenditure away from socially optimal uses, and lead to lower quality of public services, if officials determine expenditures mainly on the basis of their potential as sources of bribes. Large infrastructure projects are an obvious possibility in this respect (Mauro 1997).

At another level, corruption undermines Nigerian development in an even more pernicious manner due to the economy's dependence on oil. It is exceptionally significant that the country remains heavily dependent on the hydrocarbon sector, with oil and gas accounting for about 15 per cent of GDP, 70 per cent of government revenues and 95 per cent of export earnings.$^{20}$ Because of this oil dependence, the state has become the primary appropriator and distributor of economic surplus. Accordingly, facilitation and intermediation have come to dominate the investment process. Fortunes derived from oil licences, contract facilitation, kickbacks and commissions, and from the outright commandeering of public resources constitute the main source of capital accumulation. ${ }^{21}$ These fortunes created a wealthy economic class and financed a class

\footnotetext{
${ }^{8}$ This writer is privy to the story of a professor whose vehicle particulars were seized by two traffic policemen demanding "something" from the Oga. When he refused they held on to his papers. Reporting the incident to a Commissioner of Police who was the professor's friend, the answer was: "OF boy: make you jus' settle the boys now".

${ }^{19}$ The consequences could be tragic when that "engineer" then proceeds to supervise the construction of a public building which then collapses.

${ }^{10}$ With an average real GDP growth rate higher than seven per cent over the last decade, the Nigerian economy has been one of the best performers globally. Some of this growth has been driven by the strong performance of the non-oil sector, particularly communications and banking (Deutsche Bank, 2013). Nonetheless, the hydrocarbon sector remains the main driver. ${ }^{21}$ Marxists, recalling Karl Marx's explanation that the origins of capitalism (primitive accumulation) lie
} 
of political heavyweights who, on attaining political office, immediately commit to reproducing the vicious cycle (Ohiorhenuan, 1989). In this way, Nigerian corruption has become cumulative and self-reinforcing, as individuals and self-selected groups use its proceeds to buy political power, and then use political power to accumulate wealth in an infinite exponentially rising cycle.

It is also highly significant, from the standpoint of long-term development, that the origination of surplus in hydrocarbons makes it particularly easy to keep it out of domestic circulation. This outcome is convenient because illegally or illegitimately acquired capital tends to be shy. In a real sense, therefore, capital flight is endemic to the conditions of accumulation in Nigeria, with all that it implies for economic development. As Table 4 shows, Nigeria heads the list of African countries in terms of capital flight. ${ }^{22}$ Total capital flight from Nigeria amounts to 311 billion dollars (in constant 2010 dollars) over the forty-year period 1970 - 2010. It is noteworthy that capital flight per capita over the period is nearly twice its per capita income in 2010 ( $\$ 1966$ versus $\$ 1243$ (Boyce and Ndikumana 2012, Table A.3)]. The bulk of flight capital (88 per cent) is accounted for by the difference between recorded inflows and the recorded uses of foreign exchange, the so-called 'residual' measure of capital flight. ${ }^{3}$ The remaining 12 per cent comes from trade misinvoicing and unrecorded remittances.

Table 4: Top Ten Countries in Capital Flight from Africa, 1970 - 2010

$\begin{array}{llllll}\text { Country } & \begin{array}{l}\text { Total capital } \\ \text { flight (Billion } \\ \text { constant 2010 }\end{array} & \begin{array}{l}\text { Ratio to } \\ \text { GDP 2010 } \\ \text { (percent) }\end{array} & \begin{array}{l}\text { Stock capital } \\ \text { flight in } \\ 2010\end{array} & \begin{array}{l}\text { Debt stock } \\ \text { in 2010 } \\ \text { (Billion \$) }\end{array} & \begin{array}{l}\text { Net assets in } \\ 2010 \\ (\text { Billion S) }\end{array} \\ \text { Nigeria } & 311.4 & 158.2 & 381.1 & 7.9 & 373.2 \\ \text { Angola } & 84.0 & 101.8 & 95.9 & 18.6 & 77.3 \\ \text { Cote d'lvoire } & 56.0 & 244.4 & 81.3 & 11.4 & 69.9 \\ \text { South Africa } & 38.5 & 10.6 & 66.2 & 45.2 & 21.1 \\ \text { Sudan } & 38.4 & 57.3 & 42.7 & 21.8 & 20.9 \\ \text { Democratic } & 33.9 & 258.4 & 50.6 & 5.8 & 44.8 \\ \text { Republic of } & & & & & \end{array}$

in part in the plunder of continents, slavery and "pacification" of indigenous people, might infer similarly that corruption is our own latter day primitive accumulation.

\footnotetext{
${ }^{22}$ It doesn't seem accidental that seven of the top ten countries are oil exporters.

J The difference between recorded inflows and the recorded uses of foreign exchange provides the baseline

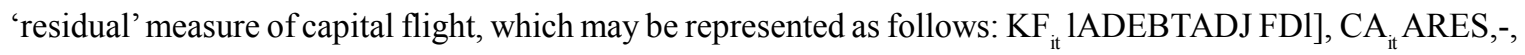
where ADEBTADJ is the change in the stock of external debt outstanding adjusted for exchange rate fluctuations, FDI is net foreign direct investment, $\mathrm{CA}$ is the current account deficit, and ARES is net additions to the stock of foreign reserves. This residual is then adjusted for trade mis-invoicing and unrecorded workers remittances. Trade mis-invoicing accounts for about 12 percent of capital flight. Surprisingly no remittances are recorded as zero.
}

110 Annals of the Social Science Academy of Nigeria, No 20, 2015 
Congo

\begin{tabular}{lccccc} 
Gabon & 25.5 & 192.9 & 31.9 & 2.3 & 29.5 \\
Ethiopia & 24.9 & 83.8 & 29.9 & 7.1 & 22.8 \\
Mozambique & 20.7 & 224.9 & 26.1 & 4.1 & 22.0 \\
Cameroon $^{20.9}$ & 89.0 & 31.3 & 3.0 & 28.3 \\
Total Africa $^{2}$ & 814.2 & 78.7 & 1065.8 & 188.6 & 877.2 \\
& \multicolumn{2}{c}{ Notes: }
\end{tabular}

1. This is the accumulated stock of flight capital, assuming that it earned interest at the short-term US Treasury Bill rate

2. The estimates only cover 33 African countries Source: Boyce and Ndikumana, 2012

The critical developmental consideration is that capital flight widens the resource gap faced by the country, impelling the continuing resort to debt and external aid. It also slows down gross domestic capital formation and long-run growth. Substantial resources are of course used domestically, and the country sees this in particular abundance during elections. While the distributive effect of massive electoral spending may be significant, it is doubtful whether it contributes much to growth, considering that most of this spending is on imports.

To sum up: Corruption in Nigeria has become ingrained in people's "mental maps", and accepted simply as (unwritten) standard operating procedure in everyday life: from responding to a "stop" command from a policeman; to requesting a licence to drive or start a small business; to bidding for contract of any size. For as long as anyone can now remember, that is how things are done. There is a common saying among the Yoruba which is: "Let us do as it is done so that things will turn out as they should." Because we accept it as "the way things are", corruption expands and reinforces itself in parthenogenetic fashion, creating the culture of vice that Nigerians have mostly resigned themselves to.

Much is known about how corruption aids or undermines development in both direct and very deep ways. However, the picture remains far from clear and, in essence, we still see corruption darkly, as through a glass. Nonetheless, despite this incomplete knowledge, some action is possible.

\section{Corruption and Institutional Reform in Nigeria}

The people must refuse co-optation and corruption and insist on justice... If we do not force those who rule us to tread the path of accountability and respect for the rule of law, we would continue in our present misery and sign a pact with eternal underdevelopment (Niyi Ouundare, The New Masquerades. The Guardian On Sunday, August 15, 1999:39).

He that is without sin among you, let him first cast a stone at her (John 8:7, King James Version). 
Suggestions abound on good approaches to curbing corruption (De Tray, 2006; Hussain, 1999; Karklins 2005; Klitgaard, 1988, 2000, 2010, 2012; Manor, 2008; Mu»giu-Pippidi 2006, 2013; Persson, Rothstein and Teorell, 2010). Indeed, Nigeria herself has had a long history of anticorruption campaigns ranging from the moral exhortations of President Shagari's "Ethical Revolution" (1979-1983); through General Buhari's "War Against Indiscipline” (1983-1985); to the setting up of the Independent Corrupt Practices Commission (ICPC) in 2000, and the Economic and Financial Crimes Commission (EFCC) in 2003. Box 2 provides a summary of the main anti-corruption efforts since 2005 .

\section{Box 2: Major anti-corruption initiatives in Nigeria.}

Operation Purge the Nation: launched by General Murtala Muhammad in 1975 with the objective of purging the country of corruption, incompetence and unethical behavior among civil servants and politicians. Fifty heads of government departments were compulsorily retired and over 11,000 civil servants were removed from service.

The Public Complaints Commission (PCC) or the Nigerian Ombudsman: established by decree as an independent body in October 1975 and given w;ide. powers to investigate complaints by members of the public regarding the administrative action of any public authority or company, or their officials. The PCC was revalidated in the 1999 Constitution.

The War against Indiscipline (WAI): launched by General Buhari in 1983 with the main objective of instilling a sense of discipline in civil servants as well as the general public.

The Public Accounts Committee (PAC): established by decree in 1987 to perform an oversight function over the spending activities of all executive offices. The PAC was mandated to examine the annual reports and comments on government accounts presented by the country's Auditor General.

The Code of Conduct Bureau: initiated in 1980 but National Assembly unable to pass the enabling bil into law. Re-initiated and established by decree in 1989 under General Babangida. It has also been enshrined into the Constitution.

The Independent Corrupt Practices Commission (ICPC) was established under the Corrupt Practices Act of 2000 as a statutory body answerable to the National Assembly and with the main purpose of fighting corruption. The ICPC was given wide powers for investigation, arrest and prosecution of suspected persons.

The Budget Monitoring and Price Intelligence Unit (BMPIU), a.k.a. Due Process was set up in 2003 to act as a restraint on corrupt practices in public procurement and service delivery.

The Economic and Financial Crimes Commission (EFCC) was established in 2003 as a law enforcement agency to investigate a wide range of financial crimes. It is empowered to prevent, investigate and prosecute offenders who engage in acts of money laundering, embezzlement, bribery, illegal arms dealing, smuggling, human trafficking, child labor, illegal oil bunkering, illegal mining, tax evasion, foreign exchange malpractices including counterfeiting, theft of intellectual property and piracy, open market abuse, dumping of toxic wastes, and prohibited goods (Waziri 2011). The Commission is also mandated to identify, trace, freeze, confiscate, or seize proceeds derived from terrorist activities

Sources: Waziri, Fatima 2011

Policy and Legal Advocacy Centre (PLAC), Abuja. Complete Laws of Nigeria. Public Accounts Committee Act; Public Complaints Commission Act. Available at: http://www.placiiK.ors/lawsofHigeria/inHle/304

112 Annals of the Social Science Academy of Nigeria, No 20, 2015 
From a conceptual viewpoint, Nigeria's anti-corruption initiatives all have one thjng in common. They are attempts to deal with corruption as a Principal-Agent problem (PAP). As is well known, a PAP arises in situations of asymmetric information in a contractual relationship. The general argument is that the agent (e.g. a manager) is better informed about a specific project or product than the principal (e.g. the shareholders). The agent uses this informational advantage to further his or her own interests at the expense of the interests of the principal. The Principal-Agent paradigm assumes that the state embodies the best interests of society. Accordingly, government officials are represented as agents and the political office holders as the principals. More broadly, the government as a whole is cast as the agent and citizens as the principals. Corruption is recognised as a major risk in the principal-agent world, for which the answer is to adjust incentives and tighten oversight. Anti-corruption campaigns are typically premised on the PrincipalAgent framework (Persson, Rothstein and Teorell 2013).

However, if corruption is systemic as in Nigeria, it presents more as a collective action problem (CAP). ${ }^{24}$ The essence of the collective action problem is that, assuming imperfect knowledge and bounded rationality, people will'choose to act corruptly as long as they expect most other people to be corrupt, even if they all realize that everyone stands to gain from eradicating corruption and even if almost everyone morally condemns corrupt practices.

The costs of not behaving corruptly can be very high and (it is believed) action at the margin is unlikely to change anything. A number of recent studies of corruption on the continent suggest strongly that systemic corruption may be better represented as a collective action problem (Kelley 2010, Persson, Rothstein and Teorell 2010).

This article's suggestions for crafting a strategy for the management of the corruption problem in Nigeria recognise both its PAP and CAP dimensions. It is too easy to assume that the state is utterly predatory. Historical experience suggests that even where corruption is pervasive, it is never total and not all state office holders are consumed by it. As such, policy can be based on the assumption that the principal-agent problem still holds to some extent even in a country like Nigeria. At the same time, other elements of anti-corruption have to be sought in collective action frameworks. The suggestions here are premised on two basic principles: realism and pragmatism.

Realism: Corruption is not a uniquely Nigerian phenomenon. It exists everywhere even if Nigeria is one of the worst cases. The point about systemic corruption is that everyone is implicated in little or big ways, whether or not we are fully aware of it. Furthermore, some of the most developed countries today have a history of corruption that dwarfs the Nigerian situation in relative terms. But they turned the corner at some point. This suggests that there is no point in either self-flagellation or triumphalism over

\footnotetext{
${ }^{24}$ Indeed, some argue that the larger issue of governance in Africa should be viewed through the collective choice prism (Booth 2012).
} 
corruption. The total eradication of corruption is unlikely, but substantial reduction is necessary and, history shows, possible. ${ }^{25}$ This article proceeds hcftvever, on the assumption that we all recognize that it is becoming a binding constraint to development, and that we wish to remove this constraint.

Corruption has been described as an act of calculation not of passion (Klitgaard 2010). Correspondingly, we should not approach the management of corruption as a sort of war against immorality. Rather a planner's perspective is indicated, which is to treat the problem as one of shifting a constraint. While we must not lose our capacity to be shocked, especially by acts of grand corruption, moral outrage in itself is not a strategy.

Pragmatism: A grand strategy approach to fighting corruption is likely to be counterproductive. Tempting as it may be to push that idea, a large-scale frontal attack is unlikely to succeed. Indeed, the only examples of success of such an approach are probably Hong Kong and Singapore and their situations are widely acknowledged as rather unique. Moreover, their success has been underpinned by a de facto totalitarian governance regime. Some might consider this a small price to pay for the eradication of an evil. However, the larger moral question is really about how much draconian and absolutist government is acceptable in order to get rid of corruption totally. This larger question is beyond our scope here, hence we look for the second best solutions and work on the progressive enlargement of the constituency of those interested in real change. We could start by targeting components of the system that offer lower pay off on the face of it but may in fact have a much higher impact on the entire system in the long term. For instance, it is more important to focus on, and hold the government accountable for delivering projects and services on time, on budget, and according to contracted specifications, than to worry about whether the contract was awarded to friends or party stalwarts. Eventually, those being held rigorously to account for results, will refrain from hiring friends or party stalwarts unless they can deliver and be seen to have delivered.

Nigeria's recent socio-economic story is that strong economic growth is occurring even in the context of substantial corruption. The dialectics of the process is generating both self-reinforcing and self-destructive dynamics. The beneficiaries of corruption get stronger and more capable of defending the status quo through coercion and mass bribery. At the same time, however, the process is also generating increasingly strong pressures for the drastic reduction of corruption as outrage grows at the excesses. The key to institutional reform lies in strengthening these forces against the vested interests that profit from systemic corruption. From a logical point of view, we understand that the dynamic of systemic corruption derives from each person's expectation that everyone else will be corrupt. What if we reach a point where more and more people are

${ }^{25}$ On this, I acknowledge a difference of opinion with former NES President Prof. Ajayi who contends that corruption must be eliminated in its totality (Ajayi 2003: 24). It may be desirable morally, but total eradication has not historically been proven as achievable.

114 Annals of the Social Science Academy of Nigeria, No 20, 2015 
refraining from corrupt practices and the expectation becomes that no one else is engaged in corrupt practices? Surely there's no reason why the same logic cannot work in reverse. Can the government do the job alone? Realistically, that would be too much to expect. First a large part of the problem does lie with government. Moreover, even where the government has expressed commitment to certain actions, implementation is often slow. Vigilance and voice are essential to ensure sustained government commitment to reducing corruption. Elected governments ultimately act out of fear of losing elections, or the desire to fulfill promises. If the public, through civil society organs and other means, keeps on insisting that government do the right thing, government may eventually gravitate towards the right thing. Some institutional reform actions by the government must remain central to an anti-corruption strategy. Some suggestions include:

- Strengthen key institutions of restraint. Significant progress has already been made, although victory cannot be declared yet. The ICPC and EFCC have rightly won praise for bringing to account some powerful people suspected of corruption. The EFCC, in particular, has helped to recover substantial sums of embezzled funds and successfully eroded the certainty of impunity. Of critical importance, the integrity of the judiciary must be fully restored and protected. Parliamentary oversight of the Executive branch and proactive legislation should be strengthened. At operational level, we really must strengthen and, if necessary, re-profile - in quantitative and qualitative terms, and in terms of robust systems of accountability - critical institutions like the police, the customs and the tax authorities.

- 'Quarantine' key entities. Japan is known to have, at one time, 'quarantined' certain key ministries from corruption, so that their resources were not diverted and the officials within them could focus entirely on performing their assigned tasks (Manor 2009). The idea would be to quarantine politically and fiscally critical ministries, as is already happening in some African countries, such as Burundi and Rwanda with their Revenue Authorities. Obvious entities for quarantining in Nigeria would include the Federal Inland Revenue Service (FIRS), the Nigerian National Petroleum Corporation (NNPC), and the Nigeria Customs Service (NCS).

\footnotetext{
${ }^{26}$ At the signing of the Power Reform Transaction contracts in April 2013, President Jonathan said: "Let me continue to assure Nigerians that yes, there are issues of corruption in this country but somehow it has been over-amplified. People should watch how we have been conducting government business. We have been bringing down the issues of corruption gradually." As reported in Premium Times Nigeria, April 22, 2013.premiumtime3ng.coin'.../130756-coiTuption-iti-nigeria-is-over-amplified-president-jonathan-says.html
} 
- $\quad$ Adjust the incentives regime. High-level public figures or institutions (domestic or foreign) that commit outrageous acts of corruption must be ma^e to bear the full weight of the law to demonstrate that there is no impunity. However, sanctions alone will not do the job. Corruption cannot be reduced substantially only by punitive measures. Positive incentives should also be put in place to discourage corruption. Such incentives could include better pay, bonuses for exemplary behaviour and social recognition for high integrity. ${ }^{27}$

Anti-corruption strategy must, however, go beyond government and involve non-state actors - the media, non-government organizations, businesses and academia in the diagnosis and remediation of corrupt systems. The role of non-state actors in the anticorruption campaign could include:

- the media to investigate and report instances of corrupt practices in depth. The passage of the Freedom of Information Act provides a strong foundation for undertaking these roles;

- non-governmental organisations to monitor corruption and maintain unrelenting anti-corruption advocacy. I would encourage NGOs to develop, to the extent possible, constructive relationships with government in identifying government entities that are performing particularly well or badly and in monitoring and reducing corruption in public services;

- academic institutions and think tanks to disaggregate corruption by sources, types, modes and destination of the proceeds, as well as show the costs of corruption at macro, meso and micro levels, and undertake comparative analysis of anti-corruption strategies, especially from other countries of the Global South;

- professional standards organisations to provide quality assurance on the implementation of major projects and delivery of critical services;

- $\quad$ private sector associations to ensure members' compliance with the respective codes of ethics; and

- religious bodies to maintain the moral high ground and build trust and harmony among various groups of society.

While acknowledging the important work that is being done by the country's anti-

\footnotetext{
${ }^{27}$ It should be noted that beyond some reasonable minimum sufficient for a decent level of living, salaries do not have a significant effect on the calculus of corruptions. Rather it depends on the size of the bribe, the chances of getting caught, the probability that sanctions will be applied and the severity of the sanctions.
} 
corruption activists, it would be unrealistic to expect any one non-state entity to assume the role of comprehensive anti-corruption vigilance. It is the dynamics of $>$ their interaction that will generate long-lasting results. The challenge is to overcome problems of coordination, credibility and collective action among the different sets of actors with their different but interdependent interests. A real opportunity which exists in this era of social media is to engage social networking as a means of coordinating and collaborating among diverse civil society entities. ${ }^{28}$

\section{Conclusion}

This article has provided a quick overview of the literature on how institutions matter for development, explored the nature of institutional failure in Nigeria and highlighted the major role that corruption has come to play in it. It has also outlined elements of what is considered a realistic and pragmatic approach to managing corruption in Nigeria.

Even as we accept the importance of institutions in the,development process, the article has argued the importance of avoiding institutional fetishism. Despite the painstaking research and progress to date in identifying the core institutions that are correlated with economic growth, and the historical circumstances that explain why these supportive institutions are weak or absent in some countries, there is still no clear evidence on why and how institutions change. In many studies, institutional variables have been shown to dominate other variables in explaining growth, but those studies do not generally have a theory that would transform regularities into causal explanations. It is also important to bear in mind that the only clear relationship between development and institutions is that good things go together. Some analysts have also argued that the co-relatedness may well be because causality runs from development to institutions, rather than the other way around.

The article highlighted three features of official corruption in Nigeria as follows. First, corrupt behavior has become a normal feature of routine interaction between citizen and state. Second, a large number of public officials derive a significant proportion of their incomes from corrupt sources on a permanent basis and third, considerations of private gain by decision makers constitute a major driver of government policy. Corruption also undermines development in a deeper manner due to the economy's exceptional dependence on hydrocarbons. This dependence makes the state the primary appropriator and distributor of capital in the economy and enables intermediary capital to dominate the investment process. As a result, corruption has become cumulative and self-reinforcing, as individuals and self-selected groups use economic wealth to enhance economic power, and political power to accumulate wealth. The origination of surplus

\footnotetext{
${ }^{28}$ Some examples of platforms, developed by NGOs or individuals, for reporting corruption and mapping patterns and trends are: "I paid a bribe" in India, "PeraNatin "to" [It's Our Money] in the Philippines, and "Saatsaam" ['clean'] in Cambodia (Klitgaard 2012).
} 
in hydrocarbons made it particularly easy historically to keep it out of domestic circulation, making capital flight endemic to the accumulation process.

Despite imperfect knowledge, some action is possible to enhance anti-corruption efforts in Nigeria.. Conceptually, we need to see corruption as both a principal-agent problem and a collective action problem. As such strategy must reflect a marriage of the two. The article also argued for realism and pragmatism in thinking about corruption. It is not a uniquely Nigerian phenomenon and, implicitly or explicitly, everyone is implicated in little or big ways. There is no point therefore, in self-flagellation or triumphalism over it. The total eradication of corruption is unlikely, but substantial reduction is necessary and, history shows, possible. Furthermore, a grand strategy approach to fighting corruption is likely to be counterproductive. We should be seeking second best solutions and working to enlarge the constituency for change. We should target components of the system that offer the least resistance on the face of it but may in fact have a much higher impact on the entire system in the long term.

The article has identified elements of a strategy involving the state on the one hand, and non-state actors on the other hand. First, on the part of the state, it is essential to strengthen key institutions of restraint. It is particularly vital to restore and protect the integrity of the judiciary. We should also strengthen parliamentary oversight of the Executive branch and, at operational level, strengthen and, if necessary, re-profile critical institutions like the police, the customs and the tax authorities. Second, we could quarantine key entities and ring fence their resources, while providing additional incentives for officials within them to focus entirely on performing their assigned tasks. Obvious entities for quarantining in Nigeria would include the Federal Inland Revenue Service (FIRS), the Nigerian National Petroleum Corporation (NNPC), and the Nigeria Customs Service (NCS). Third, we should adjust the incentives regime by bringing the full weight of the law to bear on egregious acts of corruption to demonstrate that there is no impunity, and by installing positive incentives such as better pay, bonuses for exemplary behaviour and social recognition for high integrity

For non-state actors, it is suggested that the media further enhance its role in investigating and reporting instances of corrupt practices in depth; that non-governmental organisations continue to monitor corruption and maintain unrelenting anti-corruption advocacy, and to develop constructive relationships with government in identifying good and bad practices regarding corruption and public service delivery; that academic institutions and think tanks work to disaggregate corruption by sources, types, modes and destination of the proceeds, demonstrate the real economic costs of corruption at macro, meso and micro levels, and undertake comparative analysis of anti-corruption strategies, especially from other countries of the Global South; that professional standards organisations monitor and provide quality assurance on the implementation of major projects and delivery of critical services; that .private sector associations rigorously enforce their members' compliance with the respective code of ethics; and the religious bodies continue to maintain the moral high ground and build 
trust and harmony among various groups of society. The article also stressed the importance of more intensive social networking.

It is fitting, perhaps to conclude with some final reflections on research possibilities. A basic research question would be to estimate the extent of real corruption as opposed to incompetence, as the two require different policy responses. Other issues include how corrupt deals are made and kept secret; what footprints corruption leaves behind that can be studied for its direct, indirect and induced effects; and, from the perspective of efficiency in the development process, where corrupt activities are carried out with the greatest impunity and where under the greatest vulnerability. More challenging however, is finding the optimal methodological approaches. Deep historical case studies are required in addition to the usual quantitative analysis that economists love. In addition, economists are urged to seek robust collaboration with other disciplines. Lawyers understand how legal lines can be stretched and where they are easiest to cross; accountants know the financial underbelly of corrupt practices and sociologist and anthropologists can recommend excellent qualitative methodological approaches. Certainly, it is not beyond our intellectual capabilities to come up with appropriately creative multi-disciplinary research programme

\section{References}

Acemoglu, D., and Johnson, S. (2005) Unbundling institutions, Journal of Political Economy, 113(5), 949-995.

Acemoglu, D., Johnson, S., and Robinson, J. A. (2001) The Colonial Origins Of Comparative Development: An Empirical Investigation. American Economic Review, 91(5), 1369-1401.

Acemoglu, D., Johnson, S., and Robinson, J.A. (2002) Reversal of Fortune: Geography and Institutions in the Making of the Modern World Income Distribution. Quarterly Journal of Economics, 117(4), 1231-1294.

Acemoglu, D. and Robinson, James, A. (2010) Why is Africa poor? Economic History of Developing Regions, 25(1), pp. 21-50.

Acemoglu, D. and Robinson, J. (2012) Why Nations Fail. New York. Crown Business

Ajayi, S. I. (2003) Institutions: The Missing Link in the Growth Process. Presidential address delivered at the 43rd Annual Conference of the Nigerian Economic Society held 
from 7-8 August 2002. Ibadaii: The Nigerian Economic Society.

Alesina, Alberto (1997) The Political Economy of High and Low Growth. Annual World Bank Conference on Development Economics. Washington DC. World Bank.

Aoki, M. (2001) Toward A Comparative Institutional Analysis, Cambridge (Mass.). MIT Press.

- (2007).Endogenizing Institutions and Institutional Changes. Journal of Institutional Economics, 3, 1-31

Aron, J. (2000) Growth and Institutions: A Review of the Evidence. World Bank Research Obsen>er, World Bank Group, Vol. 15(1), February, 99-135.

Bates, R. H. (2001) Prosperity and Violence: The Political Economy of Development. New York: W.W. Norton \& Company.

Boldrin, M.. Levine, David. K and Salvatore, M. (2012) A Review of Acemoglu and Robinson's Why Nations Fail. Available at http://www.dklevine.com/general/ aandiTeview.pdf

Booth, D. (2012) Development As a Collective Action Problem: Addressing the Real Challenges of African Governance. Africa Power and Politics Programme, Policy Brief No. 9, October. London, Overseas Development Institute.

Boyce James K. and Ndikumana, Leonce (2012) Capital Flight from Sub-Saharan African Countries: Updated Estimates, 1970 - 2010. Research Report. Political Economy Research Institute, University of Massachusetts, Amherst October.

Brinton, M. C and Nee, Victor (1998). The New Institutionalism in Sociology. New York: Russell Sage Foundation.

Chang, Ha-Joon (2011) Institutions and Economic Development: Theory, Policy and History. Journal of Institutional Economics 7: 4, 473-498

Deutsche Bank. (2013). Nigeria: Frontier Country Report. Frankfurt. April 17.

De Tray, Dennis. Corruption and Development: An Impolitic View. Address to the 1818 Society Fall Luncheon. November 16, 2006

120 Annals of the Social Science Academy of Nigeria, No 20, 2015 
http://www.cgdev.or.g/content/article/detail/1 4236577

Dutt, Amitava Krishna. (2011) Institutional Change and Economic Development: Concepts, Theory and Political Economy. Journal of Institutional Economics, Volume 7, Issue 4, December: 529-534

Engerman, S. L. and Kenneth L. Sokoloff, A. (2008) Institutional and Non-Institutional Explanations of Economic Differences, In Menard, Claude and Mary M. Shirley, 2008. Handbook of New Institutional Economics. Berlin, Springer.

Federal Republic of Nigeria (2003) Nigeria Governance and Corruption Survey Study; Analysis of Survey Results, Final Report.

Grief, Avner (2006) Institutions and the Path to the Modern Economy. New York: Cambridge University Press.

Hussain, I. (1999) Institutions of Restraint: The Missing Element in Pakistan's Governance. The Pakistan Development Review, 38: 4 Part I (Winter) 511-536.

Herbst, J. I.(2000) States and Power in Africa. Princeton, NJ: Princeton University Press.

Kapur, D. and Webb, R. (2000) Governance-related Conditionalities of the International Financial Institutions, G-24 Discussion Paper Series No. 6, August. United Nations Conference on Trade and Development.

Karklins, R. (2005) The System Made Me Do It: Corruption in Post-Communist Societies. Armonk, New York: M.E. Sharpe

Kelley, T. (2010) Corruption as Institution: Roadblocks to U.S.-Funded "Business Formalization" Programs in Niger Available at: http://works.bepress.com/ thomas_kelley/3

Klitgaard, R. (1988) Controlling Corruption. Berkeley. University of California Press. Klitgaard, R.(2000) Subverting Corruption. Finance and Development, 37, 2, June. Available at: . http://www.iinf.org/extemal/pubs/ft/fandd/2000/06/index.htm

Klitgaard, R. (2010) Addressing Corruption in Haiti, The American Enterprise Institute 
Working Paper Series on Development Policy Number 2, April. http://www.aei.org/paper/ ! 00099

$\gg$

Klitgaard, R. (2012) Toward a Turning Point against Corruption, Strategic Review, 2:2 (April-June)

Kpundeh,S. J. (1997) Political Will in Fighting Corruption. In Corruption and Integrity Improvement Initiatives in Developing Countries, New York: United Nations Development Programme.

La Porta, R., Lopez-de-Silanes, ,F. Shleifer, A. and Vishny, R. (1997) 'Legal Determinants of External Finance'. Journal of Finance 52: 1131-1150.

-(1998) Law and Finance. Journal of Political Economy 106: 1113-1155.

-(1999) The Quality of Government. Journal of Law, Economics and Organization 15(1): $222-282$.

Landes, D.S. (1998) The Wealth and Poverty of Nations: Why Some Are So Rich and Others are So Poor. New York: W.W. Norton \& Co.

Li, Shaomin and Jun Wu, Judy (2007) Why China Thrives Despite Corruption. Far Eastern Economic Review, April: 24-28

Manor, J.(2008) An Asianist's Perspective on the Africa Power and Politics Programme. Africa Power and Politics Programme, Discussion Paper No. 4 Dec. London, Overseas Development Institute.

Marx, K. Capital, Vol. 1. Chapter XXXI, Genesis of the Industrial Capitalist. In Marx/ Engels Collected Works, Vol. 35. London: Lawrence \&Wishart, 2005. http:// www.marxists.Org/archive/marx/works/1 867-c 1/ch31 .htm.

Mauro, P. (1997) Why Worry About Corruption? Washington DC. International Monetary Fund.

Menard, C. and Shirley, M.M. (2008) Handbook Of New Institutional Economics. Berlin, Springer.

Metz, Helen Chapin, ed. (1991) Nigeria: A Country Study. Washington: GPO for the Library of Congress.

122 Annals of the Social Science Academy of Nigeria, No 20, 2015 
http://countrystudies.us/nigeria/9.htiTi

Mungiu-Pippidi, Alina Mungiu (2013) Becoming Denmark: Historical Paths to Control of Corruption. APSA 2013 Annual Meeting Paper. Available at SSRN: http://ssrn.com/ $\underline{\text { abstract }=2301329}$

Mungiu-Pippidi, Alina Mungiu (2006) Corruption: Diagnosis and Treatment, Journal of Democracy, Vol. 17, No. 3: 86-99. Available at SSRN: http://ssrn.com/ $\underline{\text { abstract }=: 1557727}$

Musa, Idris (2011) Assessment of the Effectiveness of Anti-Corruption Institutions in the Federal Public Service of Nigeria, Dissertation submitted to the School Of Postgraduate Studies, Ahmadu Bello University in partial fulfillment for the award of Doctor of Philosophy in Public Administration. Zaria, October.

North, Douglass C. (1981) Structure and Change in Economic History. New York: Norton \& Co.

North, D. (1990) Institutions, Institutional Change, and Economic Performance, Cambridge Mass: Cambridge University Press.

-(1997) Transaction Costs through Time, In Claude Menard (ed). Transaction Cost Economics: Recent Developments, Brookfield, VT: Edward Elgar.

Nugent, J. B. and Robinson, James A. (2002) Are Endowments Fate? Centre for Economic Policy Research Discussion Paper No. 3206.

Ohiorhenuan, John F. E. (1989) Capital and the State in Nigeria. Westport, Connecticut. Greenwood Press.

Pande, R., \& Urdy, C. (2005) Institutions And Development: A View From Below, In R. Blundell, \& T. Persson (Eds.), Proceedings of the 9th World Congress Of The Econometric Society. Cambridge, UK: Cambridge University Press.

Persson, Anna, Bo Rothstein Jan Teorell, (2010) The Failure of Anti-Corruption Policies: A Theoretical Mischaracterization of The Problem. QoG Working Paper Series 2010:19, June The Quality Of Government Institute, University of Gothenburg. 
Persson, A., B. Rothstein and J. Teorell, (2013) Why Anticorruption Reforms FailSystemic Corruption as a Collective Action Problem. Governance, Volume*26, Issue 3: 449-471, July 2013

Putnam, R. (1993) Making Democracy Work: Civil Traditions in Modern Italy. Princeton, NJ: Princeton University Press.

Ribadu, N. (2009) Capital Loss and Corruption: The Example of Nigeria. Testimony before the House Financial Services Committee May 19.

Rodrik, Dani, Arvind Subramanian, and Francesco Trebbi. (2002) Institutions Rule: The Primacy of Institutions over Geography and Integration in Economic Development, Centre for Economic Policy Research Discussion Paper Series \#3643.

Rodrik, Dani., Subramanian, A. and Trebbi. F. (2004) Institutions Rule: The Primacy of Institutions over Geography and Integration in Economic Development. Journal of Economic Growth, Vol. 9, No.2, June.

Rose-Ackerman, Susan. (1999) Corruption and Government: Causes, Consequences, and Reform. Cambridge, U.K. Cambridge University Press.

Shirley, Mary M. (2008) Institutions and Development, In Menard, Claude and Mary M. Shirley, 2008. Han dbook Of New Institutional Economics. Berlin: Springer

Sokoloff, K. L. and Engerman. Stanley L. (2000) Institutions, Factor Endowments, and Paths of Development in the New World, Journal of Economic Perspectives 14(3): 217-232.

Transparency International (2009) The Anti-Corruption Plain Language Guide.

Transparency International (2013a) The 2012 Corruption Perceptions Index.http:// cpi.transparency.org/cpi2012/

Transparency International (2013b) Global Corruption Barometer 2013/Nigeria http:// www.transparency.org/gcb2013/country/?countrv=nigeria

Vargas-Hernandez, Jose G., The Multiple Faces of Corruption: Typology, -Forms and Levels. (October 21, 2009). Available at SSRN: http://ssrn.com/abstract=1413976or http://dx.doi.org/10.2139/ssm.1413976

124 Annals of the Social Science Academy of Nigeria, No 20, 2015 
Waziri, Fatima (2011) Strengthening of Anti Corruption Commissions and Laws in Nigeria. Dissertation submitted to the Graduate Faculty of the Law School in partial fulfillment of the requirements for the degree of Doctor of Juridical Science University of Pittsburgh, Pittsburgh. November.http ://d- scholarship.pitt.edu/10526/1/ strengthening of anti corruption commissions and laws Jn mgeria. pdf

Weingast, Barry R. (19950 The Economic Role of Political Institutions: MarketPreserving Federalism and Economic Development. Journal of Law, Economics and Organization 96: 132-163.

World Bank (1997) Helping Countries Combat Corruption. Washington DC World Bank. Available at: http://wwwl.worldbank. org/publicsector/ anticorrupt/ corruptn/ cor02.htm\#note5 